
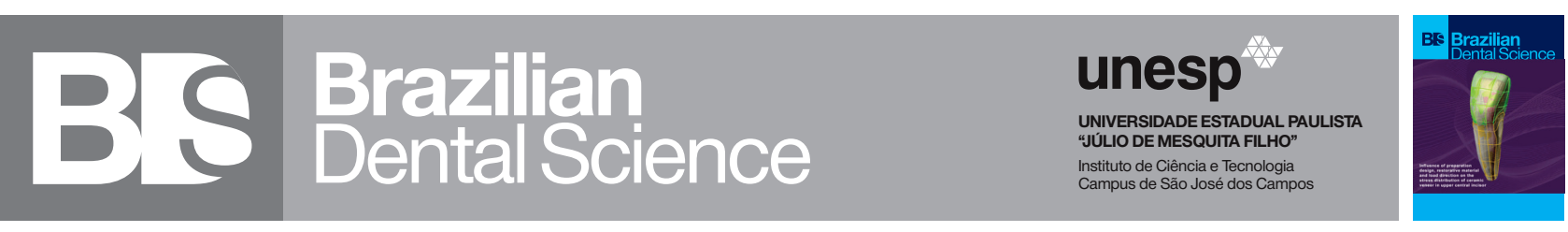

\title{
Assessment of oral health- related quality of life in patients with lichen planus during the course of treatment, using "Chronic Oral Mucosal Disease Questionnaire"
}

Avaliação da qualidade de vida relacionada à saúde bucal em pacientes com líquen plano durante o curso do tratamento, utilizando o "Questionário de Doença Oral Crônica

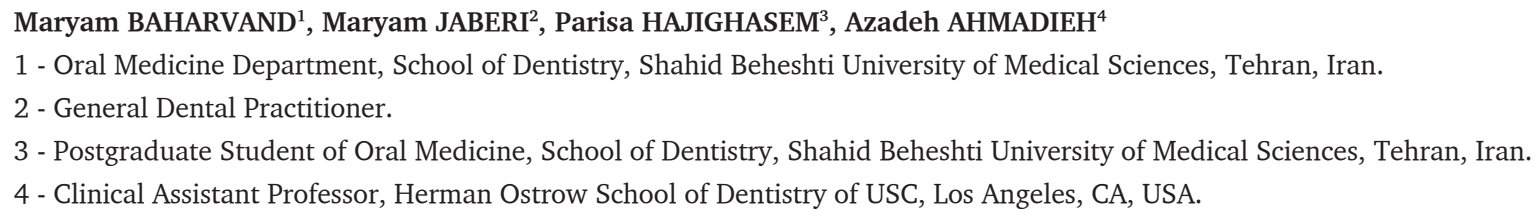

\section{ABSTRACT}

Objective: The aim of this study was to assess the oral health related quality of life in patients with oral lichen planus, using a Chronic Oral Mucosal Diseases Questionnaire (COMDQ) during a course of standard medical treatment. Material and Methods: In this experimental study, fifteen patients with oral lichen planus were entered the study and the COMDQ (a self-reported questionnaire assessing different aspects of quality of life in individuals with chronic oral mucosal diseases), was used to assess the level of "Pain and functional limitation", "Medication and treatment", "Social emotional" and "Patient support" during the course of standard treatment. A data collection form including demographic information, type and location of the lesions, patients' symptoms and level of healing process was completed. Patients were evaluated weekly during four weeks of treatment and COMDQ scores were documented. Data were analyzed, using ANOVA and Friedman statistical tests. Results: The mean score of the COMDQ questionnaire in lichen planus patients who completed the course of treatment, showed significant improvement $(\mathrm{p}<0.001)$ after each week of therapy. Oral symptoms and the healing process of oral lesions showed improvement without any statistically significant changes among different weeks of therapy. "Pain

\section{RESUMO}

Objetivo: O objetivo deste estudo foi avaliar a qualidade de vida relaciona à saúde oral em pacientes com líquen plano oral, utilizando o questionário de Doença oral crônica (Chronic Oral Mucosal Diseases Questionnaire -COMDQ) durante o curso de tratamento médico convencional. Material e Métodos: Neste estudo, foram incluídos quinze pacientes com líquen plano oral e o COMDQ (Um questionário de auto-avaliação que abrange diversos aspectos da qualidade de vida dos indivíduos com doenças orais crônicas) foi utilizado para avaliar o nível de "dor e limitação funciononal", "medicação e tratamento, "habilidades sócio-emocionais" e "suporte do paciente" durante o curso do tratamento. Também foram coletados dados como informações geográficas, tipo e local das lesões, sintomas dos pacientes e se a cicatrização das lesões foi completa. Os pacientes foram avaliados semanalmente durante 4 semanas e os escores do COMDQ foram documentados. Os dados foram analisados utilizando os testes estatísticos de ANOVA e Friedman. Resultados: O escore médio do questionário COMDQ em pacientes com líquen plano que completaram o tratamento, demonstrou melhora significativa $(\mathrm{p}<0,001)$ após cada semana de tratamento. Sintomas orais e o processo de cicatrização das lesões orais mostrou melhoras entre as diferentes semanas de tratamento, porém sem significância estatística. "Dor e limitação 
and functional limitation", "Medication and treatment" and "Patient Support" improved significantly during the treatment period $(\mathrm{p}<001)$; however, the "Social and emotional" aspect did not show significant changes over the course of medical management. Conclusion: Oral health-related quality of life in patients with oral lichen planus improved significantly during the course of medical treatment.

\section{KEYWORDS}

Oral Lichen Planus; COMDQ; Quality of Life; Oral Health.

\section{INTRODUCTION}

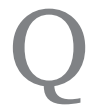
uality of life is defined as a person perception of his/her satisfaction from important aspects of life [1]. Oral health-related quality of life (OHRQoL) is derived from impact of oral life on social life and individual positive perception of dental-face statues [2]. OHRQoL describes as "a multidimensional construct that reflects individual's comfort when eating, sleeping, and engaging in social interaction as well as their self-esteem and satisfaction regarding their oral health" [3]. OHRQoL is influenced by different entities including functional factors, psychological and emotional status, and experience of pain or discomfort. Oral function may affect social life; for example, optimal dental function helps with proper nutrition, which subsequently affects patient's health. On the other hand, unhealthy teeth can lead to nutritional imbalance, compromised esthetic, and low self-esteem that impact social and occupational relationships [3].

Oral lichen planus (OLP) is a chronic immunologically-mediated disorder, where stress, anxiety and other factors related to the immune system act as possible causative or trigger factors $[4,5]$. functional, "Medicação e tratamento"e "suporte do paciente" aumentaram significativamente durante o período de tratamento ( $\mathrm{p}<0,001$ ); No entanto, "habilidades sócio-emocionais" não apresentou alterações significantes durante o curso do manejo clínico. Conclusão: Qualidade de vida relacionada à saúde oral em pacientes com líquen plano melhora significativamente no decorrer do tratamento médico.

\section{PALAVRAS-CHAVE}

Líquen plano oral; COMDQ; Qualidade de vida, Saúde oral.
Chronic diseases of the oral mucosa can definitely affect patients' quality of life. In fact, several studies have assessed OHRQoL in patients having oral lesions [6-9] using various tools and questionnaires. These tools are used to complete clinical evaluations and reinforce the relationship between patients and physicians. Moreover, patients may have a better understanding about the outcome of the diseases on their daily lives and quality of life. Assessment of OHRQoL using specialized questionnaires helps clinicians to move toward a patient-focused and health care criterion that considers individual's physical, social and emotional status to settle treatment plans and outcomes [6].

Questionnaires can be found useful in the field of oral and dental health evaluation. Chronic Oral Mucosal Disease Questionnaire (COMDQ), developed by Riordain et al, has been used to evaluate patients' mental dimensions and life quality. The COMDQ is a single discipline questionnaire with minimal timeconsumption in comparison to similar tools; that allows simultaneous physical and psychological evaluation of OHRQoL. In addition, it involves patients to assist with response to treatment [10]. The reliability and validity of this questionnaire has been verified in both English and Farsi versions [11,12]. It consists of 26 questions 
divided into four domains: "Pain and functional limitations," "Medications and treatment", "Social and emotional" and "Patient support".

Karbach et al. did not observe a significant difference in pre-treatment OHRQoL between patients with OLP, oral leukoplakia and oral squamous cell carcinoma, using the OHIP-G14 questionnaire [14]. Motallabnejad et al. studied OHRQoL in patients with OLP, using GHQ-28 questionnaire and concluded that quality of life of OLP patients were inferior to healthy individuals considering functional limitation and physical disability. However, no significant difference was observed between two groups in terms of mental disorders [15].

According to available evidence, several studies have been accomplished regarding quality of life in lichen planus patients [15-18]. Nonetheless, only few have addressed quality of life following medical treatment [17]. In addition, number of studies on quality of life in patients with OLP using specialized questionnaire is also limited. Herein, we aim to assess alterations in OHRQoL among lichen planus patients who underwent medical therapy utilizing COMDQ.

\section{METHODS}

\section{A) Study Design} study.

The present study is a prospective cohort

\section{B) Participants}

Eighteen patients, referred to Oral Medicine Department of Shahid Beheshti University of Medical Sciences, were selected and underwent clinical examination. Three patients who were either not compliant with the treatment, or were too young $(<20 \mathrm{y} / \mathrm{o})$ or too old $(>60 \mathrm{y} / \mathrm{o})$ or did not show up on follow up sessions (exclusion criteria) were excluded from the study; 15 patients ( 8 men and 7 women) who met the inclusion criteria (erythematous, ulcerative or bullous types of lichen planus and compliant with the course of treatment) were able to complete the study.

\section{C) Evaluation of oral symptoms}

Informed consent forms were signed by patients. Clinical examination was performed to confirm the diagnosis of LP. Histopathological assessment was added if necessary, to help with confirmation of diagnosis. Patients' demographic information, type and location of the lesions, symptoms onset, and COMDQ scores (before start the medical treatment) were documented (Table I). Oral lesions were scored 0 to 4 depending on the severity of the symptoms: 0 indicating no symptoms and 4 the worst symptoms possible (with intolerable and persistent pain) [19].

Table I - General characteristics of patients

\begin{tabular}{|c|c|c|c|c|}
\hline Count & $\begin{array}{l}\text { type of lichen } \\
\text { planus }\end{array}$ & $\begin{array}{l}\text { location of lichen } \\
\text { planus }\end{array}$ & sex & age \\
\hline 1 & erythematous & $\begin{array}{l}\text { anterior gingiva \&right } \\
\text { buccal mucosa }\end{array}$ & female & 48 \\
\hline 2 & erythematous & bilateral buccal mucosa & male & 28 \\
\hline 3 & erythematous & bilateral buccal mucosa & male & 51 \\
\hline 4 & erythematous & bilateral buccal mucosa & male & 53 \\
\hline 5 & erythematous & bilateral buccal mucosa & male & 56 \\
\hline 6 & erythematous & left buccal mucosa & male & 39 \\
\hline 7 & erythematous & $\begin{array}{l}\text { palate \&right buccal } \\
\text { mucosa }\end{array}$ & male & 61 \\
\hline 8 & erythematous & right buccal mucosa & female & 41 \\
\hline 9 & erythematous & right buccal mucosa & male & 55 \\
\hline 10 & ulcerative & $\begin{array}{l}\text { anterior gingiva \&left } \\
\text { buccal mucosa }\end{array}$ & male & 59 \\
\hline 11 & ulcerative & $\begin{array}{l}\text { inner surface vermilion } \\
\text { \&bilateral buccal mucosa }\end{array}$ & female & 33 \\
\hline 12 & ulcerative & left buccal mucosa & female & 56 \\
\hline 13 & ulcerative & $\begin{array}{l}\text { palate \&bilateral buccal } \\
\text { mucosa }\end{array}$ & male & 29 \\
\hline 14 & ulcerative & $\begin{array}{l}\text { palate \&right buccal } \\
\text { mucosa }\end{array}$ & female & 27 \\
\hline 15 & ulcerative & $\begin{array}{l}\text { tongue \&left buccal } \\
\text { mucosa }\end{array}$ & male & 45 \\
\hline
\end{tabular}

It should be noted that the validity and reliability of COMDQ have already been confirmed in previous studies [11-13]. In the present study, healing process of oral lesions was recorded using a relative frequency ranking $(0$ in 
case of complete resolution, 1 in case of partial resolution, and 2 in case of no improvement). Complete recovery was described by; absence of symptoms and complete resolution of the lesions, remaining of some white striae was acceptable. Alleviation of symptoms with presence of white striae and some areas of erythema indicated relative improvement. Persistent symptoms and worsening of the lesions were explained as refractory to the treatment and defined as no improvement [20].

\section{D) Measurement of quality of life}

The COMDQ consists of 26 questions that are divided into 4 parts: 1) Pain and functional limitations (including 9 questions, and score can be ranging from 0 to 36), 2) Medications and treatment (consists of 6 questions, scoring from 0 to 24), 3) Social and emotional factors (include 7 questions, ranging from 0 to 28) and 4) Patient support (contains 4 questions, scoring from 0 to 16). Each question in the questionnaire can be scored from 0 to 4 depending on the severity of the condition. The patient's final score could be ranging from 0 to 104; with a lower score indicating a better quality of life related to oral health.

\section{E) Procedure and treatment}

Treatment protocol consisted of applying topical steroid $(0.5 \mathrm{ml}$ of dexamethasone tablet was dissolved in $5 \mathrm{ml}$ of cold boiled water and was rinsed for 5 minutes) and Nystatin 100,000 $\mathrm{U} / \mathrm{ml}$ suspension ( $5 \mathrm{ml}$ was rinsed for 5 minutes). Nystatin suspension was added to the regimen to prevent "Candidiasis" a common side- effect of steroid treatment for all patients. This regimen was repeated 4 times a day, while, Nystatin was used 30 minutes after applying the steroid. [21]. Patients were examined weekly during a 4 weeks period, to assess the healing level of oral lesions. COMDQ was completed by the patients and was scored accordingly, during each visit [22]. Study by Carrozzo and Gandolfo was used to explain different treatment responses. They conducted a 30-year review literature regarding medical treatment protocols of lichen planus [20]. All findings about each patient during the treatment period and examinations were recorded in the relevant data forms. (Ethics approval: IR.SBMU. DRC.REC.1398.071)

\section{F) Data analysis}

Data was analyzed by repeated measurement ANOVA and Friedman statistical tests and SPSS 22 software. The significance level was considered 0.05 .

\section{RESULTS}

The mean total COMDQ scores significantly decreased in lichen planus patients during different stages of treatment ( $\mathrm{p}<0.001$ ) (Table II). Meanwhile, pairwise comparisons of COMDQ scores showed significant improvement on weekly basis $(\mathrm{p}<0.001)$.

In regards to evaluation of patients' oral symptoms, the intensity of pain decreased in consecutive weeks of treatment; however, this difference was not significantly meaningful ( $p$ $>0.05$ ) (Table III).

Healing process of patients' oral lesions, showed improvement through the course of treatment; yet, the difference was not significant (p >0.05) (Table IV).

COMDQ areas of assessment ("Pain and functional limitation", "Medication and treatment", 'Social and emotional" and "Patient support" showed improvement in all areas (mean total scores were decreases).

"Pain and functional limitations" assessment showed decrease in mean total scores during consecutive weeks of medical treatment; pairwise comparison also showed significant improvement when comparing the mean scores of all four weeks ( $\mathrm{p}<0.001)$ (Figure 1).

"Medication and treatment" evaluation, showed the mean scores decreased significantly 
through the course of medical treatment, when comparing the first and second weeks of treatment with the other weeks $(\mathrm{p}<0.001)$; nonetheless, the decrease was not significant when comparing the third week of therapy with the fourth week $(\mathrm{p}=0.83)$ (Figure 2).

Regarding the "Social and emotional" domain, the average score of patients during consecutive weeks of medical treatment increased from first week to second week and then decreased from second week to the third and fourth weeks. Moreover, in pairwise comparisons between treatment interval scores, there was a significant difference between week 1 with 2,3 and 4 (p <0.001), week 2 with weeks 1 and 4 ( $\mathrm{p}=0.006)$ and week 3 with weeks 1 and 2 (p $=0.002$ ). But there was no significant difference between weeks 2 and $3(\mathrm{p}=0.56)$ and weeks 3 and $4(\mathrm{p}=1.00)$ (Figure 3$)$.

In regards to area of "Patient support", patients' scores decreased during consecutive weeks of medical treatment. Pairwise comparisons confirmed this data by showing significant improvement when comparing the scores of weeks 1,2 and 3 with other weeks of therapy $(\mathrm{p}<0.001)$. However, there was no significant difference observed between week 3 and week 4 ( $\mathrm{p}=1.00)$ (Figure 4).

Table II - The mean of total scores of COMDQ questionnaire in patients during different stages of treatment

\begin{tabular}{|c|cc|c|}
\hline Time & Mean & SD & Pvalue* $^{*}$ \\
\hline Week1 & 67.26 & 6.54 & \\
\hline Week2 & 52.00 & 13.28 & 0 \\
\hline Week 3 & 34.53 & 21.52 & 0.001 \\
\hline Week 4 & 27.73 & 13.21 & \\
\hline
\end{tabular}

${ }^{\star}$ Repeated Measure ANOVA, SD: standard deviation

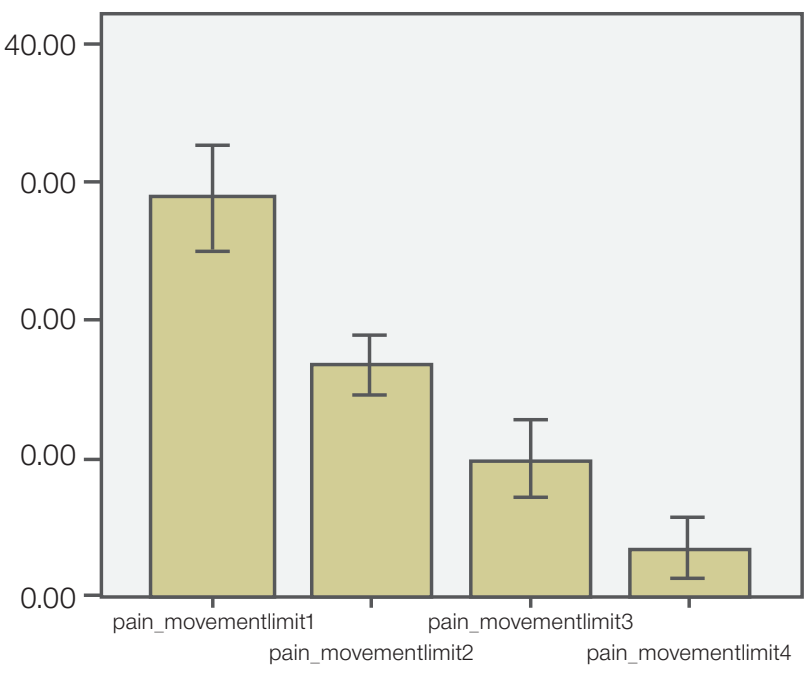

Figure 1 - Mean scores in the field of "pain and movement limitation" in patients during different stages of treatment.

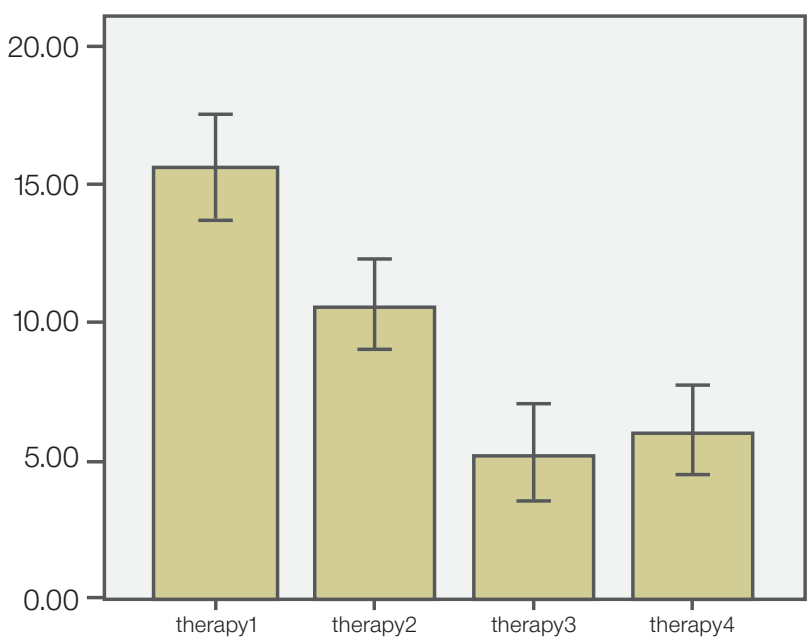

Figure 2 - Mean scores of "treatment" domain in patients during different stages of treatment.

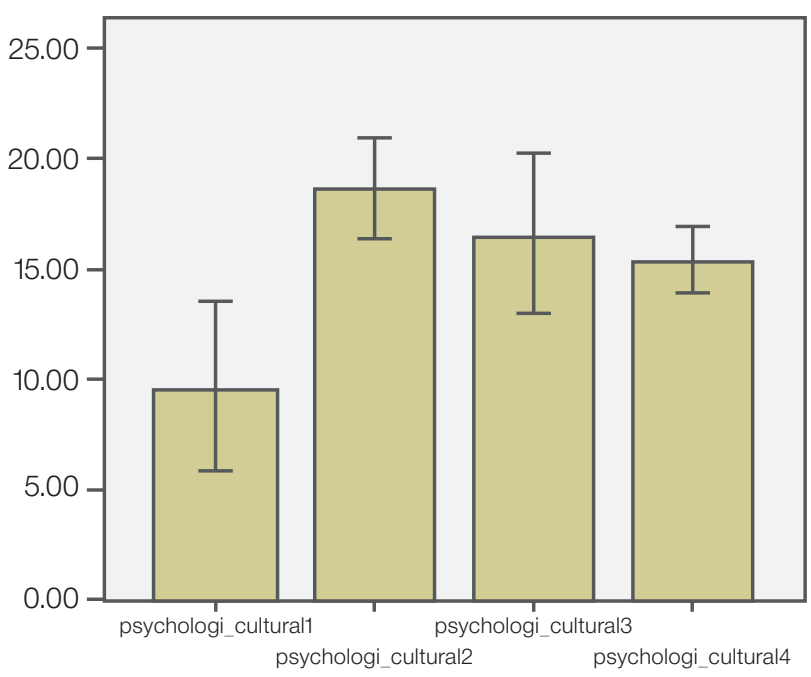

Figure 3 - Mean scores of "psychological and social" domain in patients during different stages of treatment. 


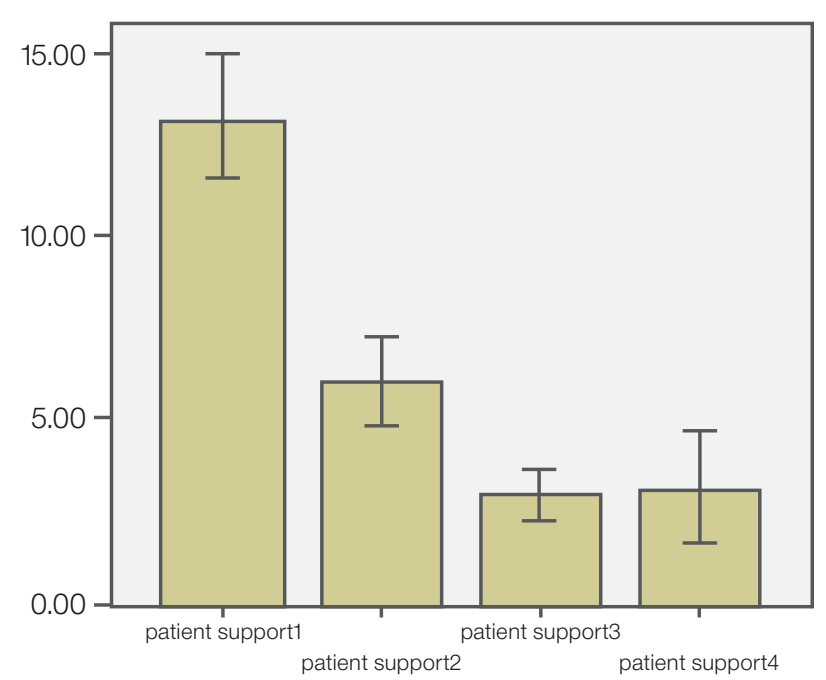

Figure 4 - Mean scores of "Patient Support" domain in patients during different stages of treatment.

Table III - Comparison of oral symptoms(pain) reported by patients in different weeks of treatment

\begin{tabular}{|cccc|}
\hline Time & symptom mild & $\begin{array}{c}\text { symptom } \\
\text { moderate }\end{array}$ & $\begin{array}{c}\text { symptom } \\
\text { intolerable }\end{array}$ \\
\hline Week1 & $\% 26.67$ & $\% 53.33$ & $\% 20$ \\
& $(4)$ & $(8)$ & $(3)$ \\
\hline Week2 & $\% 26.67$ & $\% 53.33$ & $\% 20$ \\
& $(4)$ & $(8)$ & $(3)$ \\
\hline Week3 & $\% 26.67$ & $\% 60$ & $\% 13.33$ \\
& $(4)$ & $(9)$ & $(2)$ \\
\hline Week 4 & $\% 26.67$ & $\% 66.66$ & $\% 6.67$ \\
& $(4)$ & $(10)$ & $(1)$ \\
\hline
\end{tabular}

Table IV - Comparison of healing process reported by patients in different weeks of treatment

\begin{tabular}{|ccccc|}
\hline Time & $\begin{array}{c}\text { No } \\
\text { Improvement }\end{array}$ & $\begin{array}{c}\text { Partial } \\
\text { Recovery }\end{array}$ & $\begin{array}{c}\text { Complete } \\
\text { Recovery }\end{array}$ & P Value \\
\hline Week1 & $\begin{array}{c}\% 20 \\
\% 60\end{array}$ & $\begin{array}{c}\% 20 \\
(9)\end{array}$ & 0.8 \\
\hline Week2 & $\begin{array}{c}\% 13.33 \\
(2)\end{array}$ & $\begin{array}{c}\% 60 \\
(9)\end{array}$ & $\begin{array}{c}\% 26.67 \\
(4)\end{array}$ & 0.8 \\
\hline Week3 & $\begin{array}{c}\% 13.33 \\
(2)\end{array}$ & $\begin{array}{c}\% 60 \\
(9)\end{array}$ & $\begin{array}{c}\% 26.67 \\
(4)\end{array}$ & 0.8 \\
\hline Week 4 & $\begin{array}{c}\% 6.67 \\
(1)\end{array}$ & $\begin{array}{c}\% 66.66 \\
(10)\end{array}$ & $\begin{array}{c}\% 26.67 \\
(4)\end{array}$ & 0.8 \\
\hline
\end{tabular}

\section{DISCUSSION}

We demonstrated that oral health- related quality of life (COMDQ score), after application of an approved treatment modality, significantly improved which indicates the effectiveness of such a treatment for oral lichen planus lesions.
This study also showed that patients' symptoms decreased to some extent during treatment intervals and those with moderate to severe complaints revealed a greater reduction in their symptoms.

Regarding the healing process of oral lesions, first and second week evaluation confirmed improvement from "lack of resolution" to "relative resolution" or from "relative resolution" to "complete resolution". This improvement was endorsed through 4th week of treatment (without significant change on 3rd week compared to second).

In evaluating the results of "Pain and functional limitation" area, OHRQoL in patients has significantly improved in this area. This finding ensures the effectiveness of the medical treatment that contradicts the study by Lavaee et al. that evaluated QoL in patient with ulcerative oral lesion following treatment and found that there was a significant lower QoL for pain and functional limitation [23].

"Medication and treatment" domain evaluation showed significant improvement until third week, but did not increase significantly from third to the fourth week. This finding might show insufficient patients' compliance to the treatment regimen after 3rd week. This could have been due to loss of motivation to adhere to treatment protocol during the 4th week.

"Social and emotional" domain evaluation also confirmed some improvement between treatment intervals, yet this was not statistically significant. This might have been due to lack of significant improvement of oral lesions, which in turn had a negative impact on psychological and emotional condition of patients. This was similar to findings of Lavaee et al study [23].

Regarding "Patient support", oral healthrelated quality of life (OHRQoL) showed a significant increase during the treatment weeks, except for the last week, where no significant difference was found. Patient support in the COMDQ means patients' satisfaction with treatment. Therefore, this finding can be justified by the fact that during the first 3 weeks 
of therapy, patients had adherence to treatment; however, in last week of intervention, their expectations were not met. This is probably due to the chronicity of the disease and mismatch between observed and expected healing process.

Based on the results of the present study, there is a decrease of more than 25 points in total score of COMDQ, which translates to better OHRQoL during treatment period. A decrease in scores of "Pain and function limitation", "Medication and treatment" and "Patient support" were observed. However, despite improvement in oral symptoms and resolution of lesions, improvement of patients' OHRQoL in these areas, were not significant.

The COMDQ-15 is a brief, easy to use, valid and reliable method that can give an overview of the patient's perspective on QoL related to their chronic oral mucosal conditions. Wiriyakijja et al. [24] found reduced QoL in OLP patients with high pain levels, high anxiety levels, stress and use of topical corticosteroids.

Rajan et al. [10] also showed a significant relationship between all aspects of COMDQ, but even after treatment, chronic oral diseases such as lichen planus, pemphigus and chronic aphthous still had negative impact on patients' quality of life. Namrata and Kumar [25] in evaluating OHRQoL in chronic mucosal patients including leukoplakia, oral aphthous, lichen planus and submucosal fibrosis using COMDQ concluded that even after treatment, chronic mucosal diseases might have a negative effect on patients' quality of life, and implementation of the COMDQ may allow physicians to more effectively follow their patients. Using COMDQ can also involve patients to mutually participate in decision making regarding their treatment.

The results of the study by Lavaee et al. [23] in assessing the quality of life of patients with oral ulcers based on COMDQ showed that all COMDQ features are inter-related; these variables affected the quality of life of patients interchangeably and improvement in any area had a positive effect on patients' total quality of life.
In general, quality of life can be affected by demographic and cultural, ethnicity and dental services differences and other issues effective in the results of studies.

\section{Acknowledgment}

The authors would like to thank all individuals whose participation made this study possible.

\section{CONCLUSION}

Assessment of oral health-related quality of life of patients with oral lichen planus using COMDQ, showed significant improvement during the course of treatment in areas of "Pain and functional limitation", "Medication and treatment" and "Patient support". However, no significant changes were observed in the "Social and emotional" aspects.

\section{Funding}

Not applicable

\section{Conflicts of interest}

The authors declare that they have no conflict of interest.

\section{Ethics approval}

IR.SBMU.DRC.REC.1398.071

\section{REFERENCES}

1. Becker M, Diamond R, SainfortF. A new patient focused index for measuring quality of life in persons with severe and persistent mental illness. Qual Life Res. 1993 Aug;2(4):239-51. doi: 101007/BF00434796. PMID: 8220359.

2. Inglehart MR, Bagramian RA, editors (2002). Oral health-related quality of life: an introduction. In: Oral health-related quality of life. Chicago: Quintessence Publishing Co Inc. p1-6.

3. Gift HC, Redford M. Oral health and the quality of life. Clin Geriatr Med. 1992 Aug;8(3):673-83. PMID: 1504951.

4. Nosratzehi T. Oral Lichen Planus: An Overview of Potential Risk Factors, Biomarkers and Treatments. Asian Pac J Cancer Prev. 2018 May 26;19(5):1161-1167. doi:10.22034/APJCP.2018.19.5.1161.PMID:29801395; PMCID: PMC6031815.

5. Glick M. Burket's Oral Medicine. 12th ed. PMPHUSA. 2015. 732p.

6. López-Jornet P,Camacho-Alonso F. Quality of life in patients with oral lichen planus. J Eval Clin Pract. 2010 Feb;16(1):111-3. doi: 10.1111/j.13652753.2009.01124.x. PMID: 20367822. 
7. Tabolli S, Bergamo F, Alessandroni L, Di Pietro C, Sampogna F,Abeni D. Quality of life and psychological problems of patients with oral mucosal disease in dermatological practice. Dermatology. 2009;218(4):314-20. doi: 10.1159/000196973. Epub 2009 Jan 28. PMID: 19174600.

8. Hegarty AM, McGrath C, Hodgson TA, Porter SR. Patient-centred outcome measures in oral medicine: are they valid and reliable? Int J Oral Maxillofac Surg. 2002 Dec;31(6):670-4. doi:10.1054/ijom.2002.0260. PMID: 12521327.

9. Llewellyn $\mathrm{CD}$, Warnakulasuriya $S$. The impact of stomatological disease on oral health-related quality of life. Eur J Oral Sci. 2003 Aug;111(4):297-304. doi: 10.1034/j.1600-0722.2003.00057.x. PMID: 12887394.

10. Rajan B, Ahmed J, Shenoy N, Denny C, Ongole R, Binnal A. Assessment of quality of life in patients with chronic oral mucosal diseases: a questionnaire-based study.Perm J. 2014 Winter;18(1):e123-7. doi: 10.7812/ TPP/13-095. PMID:24626087; PMCID:PMC3951046.

11. Ni Riordain R, McCreary C. Validity and reliability of a newly developed quality of life questionnaire for patients with chronic oral mucosal diseases. J Oral Pathol Med. 2011Sep;40(8):604-9. doi:10.1111/j.1600-0714.2011.01021.x. Epub 2011Feb 25. PMID: 21352382.

12. Shirzad A, Bijani A, Mehryari M, Motallebnejad M, Mohsenitavakoli S. Validity and reliability of the persian version of the chronic oral mucosal diseases questionnaire. Caspian J Intern Med. 2018 Spring;9(2):127-133. doi: 10.22088/ cjim.9.2.127.PMID:29732029; PMCID: PMC5912219.

13. Ni Riordain R, McCreary C. The use of quality of life measures in oral medicine: a review of the literature. Oral Dis. 2010 Jul;16(5):419-30. doi: 10.1111/.j.1601-0825.2009.01647.x. Epub 2010 Mar 9. PMID: 20233325.

14. Karbach J, Al-Nawas B, Moergel M, Daubländer M. Oral health-related quality of life of patients with oral lichen planus, oral leukoplakia, or oral squamous cell carcinoma. J Oral Maxillofac Surg. 2014 Aug;72(8):1517-22. doi: 10.1016/j.joms.2014.04.008. Epub 2014 Apr 21.PMID:25037185.

15. Motallebnezhad M, Moosavi S, Khafri S, Baharvand M, Yarmand F, CHangiz S Evaluation of mental health and oral health related quality of life in patients with oral lichen planus. JRes Dent Sci. 2014;10(4):252-9.

16. Okumus 0, Kalkan S, Keser G, Pekiner FN. Awareness assessment in Turkish subpopulation with chronic oral mucosal diseases. Eur J Dent. 2015 0ctDec;9(4):564-572. doi: 10.4103/1305-7456.172633.PMID:26929697;PMCID: PMC4745240.
17. Lee YC, Shin SY, Kim SW, Eun YG. Intralesional injection versus mouth rinse of triamcinolone acetonide in oral lichen planus: a randomized controlled study. Otolaryngol Head Neck Surg. 2013 Mar;148(3):443-9. doi: 10.1177/0194599812473237. Epub 2013 Jan 16. PMID:23325710.

18. Lodi G, Scully C, Carrozzo M, Griffiths M, Sugerman PB, Thongprasom K. Current controversies in oral lichen planus: report of an international consensus meeting. Part 2. Clinical management and malignant transformation. Oral Surg Oral Med Oral Pathol Oral Radiol Endod. 2005 Aug;100(2):164-78. doi: 10.1016/j.tripleo.2004.06.076. PMID: 16037774.

19. Singh AR, Rai A, Aftab M, Jain S, Singh M. Efficacy of steroidal vs nonsteroidal agents in oral lichen planus: a randomised, open-label study. J Laryngol Otol. 2017 Jan;131(1):69-76. doi: 10.1017/S0022215116009658. Epub 2016 Dec 5. PMID: 27917729.

20. Carrozzo M, Gandolfo S. The management of oral lichen planus. Oral diseases. 1999;5(3):196-205.

21. Jajarm HH, Falaki F, Mahdavi O. A comparative pilot study of low intensity laser versus topical corticosteroids in the treatment of erosive-atrophic oral lichen planus. Photomed Laser Surg. 2011 Jun;29(6):421-5. doi:10.1089/ pho.2010.2876. Epub 2011 Jan 8. PMID: 21214369.

22. Lopez JornetP,Aznar-Cayuela C. Efficacy of topical chamomile management vs. placebo in patients with oral lichen planus: a randomized double-blind study. J Eur Acad Dermatol Venereol. 2016 0ct:30(10):17831786. doi: 10.1111/jdv.13770. Epub 2016 Jun 21. PMID: 27324515

23. Lavaee F, Sadeghzadeh, A. Afroozi B, Golkari A, Piri-Zarrini A. Evaluating the quality of life inpatients with ulcerative oral lesions. J Oral Health Oral Epidemiol. 2019;8(4):198-203. doi : 10.22122/JOHOE.V814.1019.

24. Wiriyakijja P,Porter S, Fedele S, Hodgson T, McMillan R, Shephard M, N Riordain R. Health-related quality of life and its associated predictors in patients with oral lichen planus: a cross-sectional study. Int Dent J.2020 Sep 1. doi: 10.1111/idj.12607. Epub ahead of print. PMID:32875594.

25. Namrata M, Kumar VJ. Assessment of quality of life in patients with chronic oral mucosal diseases: A questionnaire-based study. Int J Orofacil Biol. 2017;(1):24-27. doi: 10.4103/ijofb.jjofb 3 _ 16

\section{Parisa Hajighasem}

\section{(Corresponding address)}

School of Dentistry, Shahid Beheshti University of Medical Sciences, Daneshjoo Blvd, Evin St, Chamran High Way, Tehran, Iran (Zip Code:1983963113).

Email: ib.hajighasem@gmail.com

Date submitted: 2020 Aug 23

Accept submission: 2020 0ct 28 